Srna MANDIČ, Valentina HLEBEC**

\title{
CONTROL OVER ONE'S LIFE DURING THE COVID EPIDEMIC: A CASE STUDY OF MULTI-APARTMENT BUILDINGS IN LJUBLJANA**
}

\begin{abstract}
We examined the changing sense of control over one's life during epidemics. Using original survey data during the first lockdown in May 2020 our case study focuses on Ljubljana s multi-apartment buildings $(M A B)$ which, due to the physical proximity of the residents and the common spaces/facilities represent a distinct case with its particular threats (infection spread) and potential resources (neighbourly support) for coping with epidemic-related problems. We found a dramatic drop in perceived control over one s life, from $75 \%$ of respondents in usual times to 35\% during the pandemic. Accounting for a range of epidemic-associated occurrences in the building and among the residents our regression analysis shows their significant impact on residents sense of control that highly exceeding those of the quality of life and of basic socio-demographic characteristics. While our case study demonstrates that the specific setting of an $M A B$ can provide a valuable layer of human action in times of crisis, further research is needed to permit generalisations.
\end{abstract}

Keywords: pandemic, perceived control over one's life, ontological security, multi-apartment buildings, wellbeing, control over one's life

\section{Introduction}

The Covid-19 pandemic has brought a host of new problems and issues of unprecedented scope and magnitude that question the ability of societies and individuals to deal with them. The outbreak has also produced an additional global health crisis and led to mental health problems like stress,

* Srna Mandic, PhD, Senior Research Fellow, Centre for Welfare Studies, Faculty of Social Studies, University of Ljubljana, Slovenia; Valentina Hlebec, PhD, Professor, Faculty of Social Studies, University of Ljubljana, Slovenia.

** This work was supported by the Slovenian Research Agency: Quality of Life of Social Groups [P5$0200(B)]$.

DOI: $10.51936 /$ tip.58.specialissue. $555-575$ 
anxiety, depressive symptoms, insomnia, anger and fear globally (Torales et al., 2020), social isolation, uncertainty or the exacerbation of depressive, anxiety, substance use and other psychiatric disorders (Sher, 2020). The pandemic has been shown to be associated with highly significant levels of psychological distress, post-traumatic stress disorders that often reach the threshold for clinical relevance (Xioh, 2020).

While public discourse on the pandemic has been dominated by biomedical perspectives and seen it as a bio-medical phenomenon, social scientists may define and examine the pandemic as a social phenomenon. Pfister (2020) maintains the pandemic has become a social phenomenon through various processes of social construction, where the emphasis is on certain risk categories while neglecting others, meaning the risk of the pandemic is the outcome of "an interwoven assemblage of probabilities, categories, values and time-frames".

Since the virus and the spread of the infection cannot be directly observed, for most people they have become evident through general information, social practices and particularly changes in their daily lives. Here, most crucially, the pandemic poses an unprecedented challenge to many of the assumed certainties in our lives since the habitual settings of our 556 work and lives have been altered (Consolli, 2020). As contended by Repohl (2020), the abrupt threat posed by the pandemic in day-to-day life undermines the basic feeling of 'ontological security', the experience of the world as being stable, predictable and trustworthy. Schools, playgrounds and shops, once reliable places for making contacts and socialising, have during the pandemic suddenly turned into risk zones of infection and are better avoided. A deep feeling of discomfort and insecurity lies at the bottom of the global experience during the pandemic and, as described by Repohl, signifies the loss of ontological security, a basic existential need according to Giddens (1981).

In this article, we discuss people's reaction to this Covid-driven uncertainty and examine how they have responded in terms of having control over their life during the epidemic. Control over one's life is a well-established concept, reflecting the constraints and opportunities in managing life and averting the tendency to become helpless in frustrating and aversive situations (Prenda and Lachman, 2001; Mirowsky and Ross, 2007). We focus on people's daily lives in a particular setting - the multi-apartment building (MAB). This is a special context because the residents' day-to-day life is characterised by physical proximity and the use of common spaces and facilities like corridors and lifts. Even with new practices of self-protection, distancing and watchfulness, with their more frequent contacts these spaces may indicate a hazard for the virus' spread, such as with New York's "towers of death" (Tamura et al., 2020). However, alongside its specific threats (i.e. 
infection spread), the MAB is a distinct case given its potential for neighbourly support among the building's residents to help them cope with Covid-related problems (like isolation and a greater need for emotional and service support). In other words, residents' actions may be seen as a collective response to the difficulties brought by Covid, a response that parallels the efforts made on other societal (e.g. individual or municipal) levels.

The aim of this article is to gain insight into the role of neighbourly activity during the pandemic. More specifically, we consider the question of whether during the epidemic the neighbourly occurrences in the building have impacted the residents' perceptions of having control over their lives. While it has already been established that residential action affects individuals' feeling of having control over common issues in a MAB (Mandic and Filipovič Hrast, 2019), we wish to examine this role with regard to specific threats in the pandemic. To this end, we chose the case study method which, while observing a phenomenon, recognises the importance of its particular setting and its unique occurrences. Various data capturing the situation in the city of Ljubljana during the first lockdown in 2020 were therefore collected. The lion's share of this are original data gathered via an online survey of 310 residents in an MAB, a purposive sample. As a case study, the analysis does not intend to provide generalisations - even though that might help in formulating a hypothesis - but chiefly to understand the unique phenomenon in its complexity and specificity.

The structure of the article is thus as follows. The first section provides the theoretical background to help understand the contingencies of control over one's life, with a focus on the social setting. The methodological section follows, discussing the case study method and presenting our research design. We then proceed to the presentation and analysis of the data that considers both the survey data and some general data on Ljubljana's response to the pandemic. In the conclusion, our findings and their implications are set out.

\section{Perceived control over one's life and its versatile theoretical backgrounds}

Perceived control over life is intuitively easy to understand and no doubt positively related to well-being and life management (Bond and Feather, 1988; Burack and Lachman, 1966; Prenda and Lachman, 2002). Mirowsky and Ross (2008: 7) argue that "the sense of control links the socio-economic, interpersonal, behavioural and psychological systems" and summarise, among others, the following influences identified by various disciplines. Social psychologists see a low sense of personal control as an elementary form of alienation (along with isolation and meaninglessness), which can be 
enhanced by supportive interpersonal attachments; psychologists find that a sense of control averts the tendency to become helpless in tough situations; sociologists show that the average sense of personal control rises with education, earnings, employment and declines with unwelcome events like being fired, sick, injured or exposed to various hardships.

The sense of control in life can be measured relatively simply when articulated in terms of the individual's assessment of their degree of control, namely, perceived control. It implies a person's perception of their ability to have some control over events and over wider forces that influence their life (Biron and Bamberger, 2010). Yet, understanding this sense of control is a very complex task, particularly while accounting for the broader context of complex social life. One must also confront the versatile theoretical and conceptual terrain of the social sciences and their plurality of approaches. There is the question of how to bring their vague and abstract notions closer to the specific setting of our case study to thereby help understand people's diverging responses to the adverse situation created by the pandemic. Below, three major relevant theoretical approaches are described that consider 'control over one's life' and seek to explain it from various perspectives. In our efforts to comprehensively explain our subject, we believe it

558 is necessary to combine them. Still, we wish to elaborate on neighbourly activity as a specific domain that may contribute to how residents perceive their control over their lives. This issue has yet to receive any real attention.

\section{Quality of life and well-being studies}

In this strand of social studies, the issue of control over one's life is observed and explained within the context of "quality of life" or "well-being", to use a more recent popular term. Perceived personal control in this context is seen as a significant element of quality of life and at the same time as also being influenced by other elements of quality of life. These studies originated in the 1960s when Scandinavian countries undertook nationwide surveys of the level of living and quality of life, aiming to cover all basic elements of human well-being in advanced societies. Initially, the focus was on the resources available to individuals in various life domains. The issue of 'control over one's life' was recognised as the "individual's command over resources in the form of money, possessions, knowledge, mental and physical energy, social relations, security and so on, through which the individual can control and consciously direct his living conditions" (Erikson, 1993: 73). Later, in addition to (objectively defined) resources, the subjective perceptions (satisfaction) held by respondents were also included. A more recent version of this line of study is the European Quality of Life Survey, periodically carried out since 2002 (Fahey et al., 2002; Eurofound, 2012), that is still 
distinguished by its indicator-based and policy-monitoring commitment, seeking to provide "a reasonably complete picture of actual quality of life" and "measure people's well-being" (Stiglitz et al., 2009: 12). With the course of time, these studies reveal an increasing number of elements and domains by which well-being is defined and measured. This complexity also affects 'control over one's life', now narrowly understood as 'personal autonomy', but representing 1 of 26 indicators of subjective well-being (Eurofound, 2013). More precisely, it is an element of the 'eudaimonic dimension' of subjective well-being, along with 'evaluative well-being' and 'hedonic well-being'.

However, while growing to become an umbrella term with ever more elements, 'well-being' retains its simple conceptual core. It takes the micro perspective of people's life situations with a focus on the individual's conditions and their perceptions, and empirically establishes the relevant mutual influences between elements of well-being and describes their distribution across social groups. By serving policy monitoring, the approach recognises the inherent relationship between the individual's well-being and their social circumstance and wider structural determinants. Thus, in its most recent study on the impact of Covid-19, Eurofound (2020) found how the toll of the pandemic on subjective well-being levels differed among social groups, where particularly victimised were unemployed people, those up to the age of 49, and female respondents. In countries with a full lockdown and higher infection rates, the population's mental well-being was found to have been affected more and governments have been called on to pay attention to ways of mitigating mental health risks.

This line of studies is characterised by a "universalistic approach" (Thomson and Marks, 2008b) that focuses on broad and relatively stable conditions and items, while more particular circumstances and situations require a more targeted approach.

\section{Empowerment}

With the concept of 'empowerment', the issue of one's control over one's life is observed in the context of power. Most generally, empowerment denotes the process by which individuals and groups that are otherwise powerless or deprived gain more control and influence over their lives and conditions (Kreisberg, 1992; Schulz et al., 1992; Zimmerman, 1990; Page and Czuba, 1999). By gaining more control and influence, they are able to improve their circumstances and quality of life. Empowerment is "the ongoing capacity of individuals or groups to act on their own behalf to achieve a greater measure of control over their lives and destinies" (Staples, 1990: 30).

Empowerment implies an understanding of power not as domination, but as a non-hierarchical relationship of collaboration that leads to the 
achievement of common goals, as a capacity to implement change and mobilise others for co-action (Kreisberg, 1992: 75). It requires an attitude of social involvement and the ability to act in concert with others (Koren et al., 1992; Kreisberg, 1992; Schulz et al., 1993; Schon, 1993). As a general concept, empowerment can be applied on the individual level (personal perception of one's power and the ability to achieve one's own goals), on the organisational/interpersonal level (ability to influence others) or on the community / political level (social action) (Guiterrez and Ortega, 1991; Koren et al., 1992).

Individual empowerment refers to the perception of influence and "beliefs about one's ability to produce and regulate events in life" (Bandura, 1982: 122). Individual empowerment is a complex phenomenon that contains cognitive, personality and motivational domains (Zimmerman, 1992). It also includes behavioural and contextual components since the development of personal power and the ability to act are linked to opportunities for social support and the development of interpersonal and social skills (Schulz et al., 1993: 3). Empowerment is seen as the result of a combination of reflection and action, focusing on control over events and their expectation. The expectation that future events are uncontrollable leads people towards withdrawal, alienation and depression; conversely, with the

560 expectation that future events are controllable, people are drawn towards increased psychological empowerment, proactive behaviour and reduced alienation (Zimmerman, 1990: 73-74).

Empowerment is generally measured in two ways. The indirect approach concentrates on the preconditions for the personal empowerment to occur, such as personal skills and access to organisational, social and economic resources (Schulz et al., 1993). With the direct approach, the level of the individual's empowerment is measured by one's own perception of being in control, while the exact wording is adapted to the context (see Shulz et al., 1993; Kleinhans and Elsinga, 2010; Mandic and Filipovic, 2018).

\section{Structuration theory: the specific structural context of the multi- apartment building}

Structuration theory provides a general explanatory framework for the social world beyond and past the quality of life and empowerment approaches. It also provides the grounds for addressing certain specific qualities of social life relevant to the site of our study - multi-apartment buildings and the residents' control over their lives. One's control over one's life has been found to correspond to ontological security, a notion of structuration theory (Giddens, 1981) that denotes one's sense of confidence in the certainty of one's social and material world. To better understand how this fits into the complex social framework, we now briefly sketch out the 
core premises of structuration theory before applying it to the specific site of our study - a multi-apartment building (MAB) and its residents.

According to structuration theory (Giddens, 1981), actors feel ontological security by way of experiencing some constancy and predictability in the environment in which they act, interact and utilise resources. They feel this security by drawing on their interpretative frameworks where their actions are attributed with specific meanings relative to rules and anticipated possible sanctions. To serve their purposes, reasons and motives in their action, actors employ the rules and resources available in the given structural context. Yet, the actors' ability to act and use these rules and resources depends on their capabilities and constraints. The ability to act is inherently tied to power, understood as an emergent outcome of the power game among actors; it is a product of actors' capabilities to utilise resources, which also includes knowing how to proceed in various social life contexts. Control results from relations of autonomy and dependence.

Structuration theory and its concept of "locale" can be applied to specific phenomena where actors' interactions are inherently related to a territory or physical space. In the case of an MAB, this relationship is established in the following way: by sharing common facilities and a physical space, residents develop some shared pertinent interpretations and meanings (shared problems, experiences etc.) Consequently, in the residents' life, the site represents a common specific structural context in which they can act based on particular shared meanings, knowledge and resources. This is a basis for diverse occurrences.

In a recent study relying on such an approach (Mandic and Filipovic, 2019), two occurrences were found to significantly influence the residents' feelings of being in control in such a setting. The first is "trust in neighbours", which implies a complex set of relationships and ties between residents, including some level of sense of belonging, customs and habits, norms and social control developed in the specific setting. The second occurrence is about resident 'co-action', most notably the disposition to cooperate and join forces with others in achieving some common good. Both occurrences are instances where residents can act and use various resources to realise some control over parts of their daily lives. However, these instances imply some degree of collective control, which thus contributes to the individual's feeling of being in control in such a setting.

\section{Methodology}

The outbreak of the Covid-19 pandemic in spring 2020 presented an opportunity to observe and examine the unique phenomenon of daily life changing in response to the newly emerged risks and needs of people who 
reside in the specific setting of multi-apartment buildings in Ljubljana. To seize this special and time-limited opportunity of the pandemic lockdown in Ljubljana, our team, with experience in quality-of-life research, decided to gather evidence in ways still feasible during the lockdown - an Internet survey questionnaire to which residents in Ljubljana's MABs were invited to participate in several ways. Namely, it is clearly nonprobability sampling, not intended to make inferences from the sample to the general population in statistical terms, but suitable for in-depth qualitative research where the aim is to understand complex social phenomena (Small, 2009). The sample was purposive and included Ljubljana's MAB residents willing to share their lockdown experience. These data entail rich and complex evidence that we find valuable and wish to a use in a case study of the unique social occurrences associated with the Covid pandemic in a particular setting Ljubljana's MABs.

\section{Case study as a method}

Generally stated, a case study is a research method that allows for an indepth, holistic investigation of a complex issue through detailed analysis of

562 a limited number of cases. Yin (1984: 13) described it is "an empirical inquiry that investigates a contemporary phenomenon within its real-life context ... and in which multiple sources of evidence are used". Unlike methods that seek to provide generalisations based on data acquired through large representative samples, a case study's strength lies in its ability to describe and understand phenomena in their natural settings and in their uniqueness/ particularity. Case study methodology is especially useful when the current perspective and knowledge seem inadequate, like when new events occur, where a case study can provide a holistic perspective on real-life events in their complexity (Vissak, 2010). Case studies have recently become ever more recognised in many social studies, particularly in inquiries into social issues like poverty, drug addiction, illiteracy and community-based problems, where a more complete understanding is needed and the restrictions of quantitative methods are recognised (Zainal, 2007).

The case study methodology is often used in the presence of uncertainty and underutilised because, unlike other research strategies, it does not have a codified design (Yin, 2002). In contrast to Yin's proposal for a tighter and well-structured design, Stake (1995) argued for a more flexible design that pays attention to the issue's complexity and contextuality. In addition to differences among prominent authors on how to approach the research design and definition of the case (Yazan, 2015), there is great variety in the kinds and types of case studies. Authors (Stake, 1995; Yin, 2002; Thomas, 2021; Gomm et al., 2000) propose a similar classification of case studies with 
regard to their basic features, most notably the kind of data (qualitative or quantitative), the number of cases (single or multiple), the number of units, the primacy of the case or the issue (intrinsic and instrumental) and the category according to its purpose (exploratory, descriptive or explanatory). We note that while a case study usually refers to research that considers only one or a few cases, it is not necessarily limited to that case since various cases and units can be constructed out of a naturally-occurring social situation (Gomm et al., 2000). For a case to exist, a characteristic unit must be defined and observed and related to an analytical category or a theory (Thomas, 2021: 12).

\section{Research design and data}

We start by specifying the purpose of the study because this is very relevant for defining the research design. Our study aimed to provide insights into people's feelings of control over their lives during the pandemic, especially accounting for the context of living in an MAB in Ljubljana and the experience of the unique lockdown occurrences among residents in the building. It involves an in-depth investigation of a complex issue in its reallife context, also including the city environment. Limited in making generalisations to other settings and locations, we instead pursue a detailed account of these occurrences, capturing them holistically in their uniqueness/particularity. However, in-depth analysis of a small-N purposive sample or a case study also enables patterns and causal mechanisms of interest to be identified. Apart from the level of control over life, we wish to examine how it varies with respect to different characteristics of the residents. We seek possible explanations in terms of particular personal and quality of life occurrences and, specifically, in terms of the quality of the neighbourly actions. The study may thus be classified as mainly descriptive and explanatory.

We rely on extensive data that come from a survey conducted between 5 May 2020 and 14 May 2020 using a self-administered web data collection mode, with an on-line survey questionnaire to which Ljubljana's residents of multi-apartment buildings (MABs) were invited in various ways to complete. Although not a representative sample, it may be characterised as a purposive (reflecting the participants' deliberate choice due to their characteristics) and convenience (accessibility) sample (Etikan et al., 2016). Namely, we targeted residents of MABs containing at least 9 apartments because such buildings must have a housing manager and during the pandemic this had an effect. While the survey also provides qualitative data from open questions, for this study only quantitative data are used as they relate to selected issues. The 310 surveys completed represent the 310 units for our case study. 
The study is organised as follows. We start by describing specific changes occurring in Ljubljana during the lockdown in spring 2020 that affected quality of life and the possibilities to control it. In addition to the epidemiological restrictions that impacted the whole country, a number of specific local limitations and sources affected people's mobility options and access to services and other resources. The data used are, as mentioned, mostly quantitative and come from city documentation and local media.

The next section is descriptive. Data are presented about general characteristics of the sample, the crucial elements of quality of life, perceived control over life, and the various occurrences among neighbours in MABs during the lockdown. Alongside the general description, regularities are sought between the perceived control and other features.

The final section focuses narrowly on whether and to what extent the sense of control was affected by occurrences among neighbours in the MAB during the lockdown. This question was the last to emerge by virtue of "progressive focusing" (Jazan, 2015) as the problem areas became more clarified. Has positive action among neighbours significantly added to the feeling of control during the pandemic? The sufficiently large number of units involved makes regression analysis appropriate.

\section{The case study - results}

\section{Ljubljana during the lockdown}

Ljubljana as the capital of Slovenia is a hub of educational, cultural, commerce, administrative, healthcare and other institutions and facilities that add to the relatively high quality of life of its residents, together with the large green areas and natural resorts in close proximity. With a population of 295,000 people and 132,000 housing units (SiStat, 2021), Ljubljana is considered to be a medium-sized settlement whose smaller size means that most city facilities are relatively easily to reach. However, two specific lockdown restrictions utterly changed how the city functioned in terms of spatial accessibility and the citizens' mobility: public transport saw serious disruptions and moving around was practically limited to one's own municipality (accessible at https://www.ljubljana.si/sl/aktualno/preventivniukrepi-pri-preprecevanju-okuzbe-s-koronavirusom/). People were thus left dependent on their own means of transport and restricted to their home municipality, with both dramatically impacting the functioning of social support networks that are generally recognised to play a considerable role, particularly family members.

The pandemic lockdown in Ljubljana (for a general description, accessible at https://www.ljubljana.si/sl/aktualno/ i-ukrepi-mestne-obcine-ljubljana/; 
Žerdin, 2021) profoundly changed certain basic elements of the inhabitants' quality of life. Healthcare services, generally high in quality, became quite restrained, with difficulties even in obtaining primary care and seeing the family doctor. Access to these and other public services started to depend on Internet use and having one's own transport. Unlike others, food and basic item stores remained open, while their Internet orders and home delivery to buyers increased considerably. Group sports and recreation were largely restricted, even in outdoor spaces, while the popular activity of hiking in the city's green surroundings was restricted to one's home municipality. MABs, which account for $12.7 \%$ of all of Ljubljana's buildings (SURS, 2018), were obliged to disinfect the common spaces while the residents were required to use masks and keep a distance if meeting in the common spaces (accessible at https://www.ljubljana.si/sl/aktualno/priporocila-za-stanovalce-vvecstanovanjskih-stavbah/).

For many households, this meant a new situation whereby those with jobs had to work from home; schools for most grades switched over to online classes, while kindergartens were generally closed. In a sizeable share of households, these changes created new pressures and demands to share time and space among the members. This proved quite difficult while parents working from home also had to care for their children or where there was insufficient living space.

Some occurrences were specific to Ljubljana in contrast with other Slovenian towns. The Municipality of Ljubljana responded to the situation by providing certain additional support, most notably by providing meals for children and elderly in need daily, childcare for those in need, home childcare, support for the mutual help among parents) and extra psychological support (accessible at https://www.ljubljana.si/sl/aktualno/) psihosocialna-podpora-v-casu-epidemije/). Yet, Ljubljana's uniqueness also included the political climate on the national level. Shortly before the lockdown was declared, a new government was formed in Slovenia, one characterised by little popular support and one of the lowest levels of trust in the EU (Eurofound, 2020). This was accompanied by plenty of criticism and 'cyclists' Friday protests' (Žerdin, 2021), whereas, in certain neighbourhoods and MABs, at a designated time the residents gathered by their windows or on their balconies to protest or simply socialise while singing, playing music, making noise, displaying protest slogans or flags.

\section{Residents in MABs: their life and control over it during the pandemic lockdown}

As a once-in-a-life episode, the pandemic is responsible for countless challenges that people were unprepared for and regarding which they could 
not rely much on previous experience, their own or collective. Although personal experiences and anecdotal accounts show that people's reactions to pandemic-associated issues have varied hugely, it was not possible to systematically observe them. This section brings general insights into various

Table 1: SAMPLE CHARACTERISTICS AND PERCEIVED CONTROL OVER LIFE

\begin{tabular}{|c|c|c|c|c|c|c|c|}
\hline \multirow[t]{3}{*}{ Variables } & \multicolumn{3}{|c|}{ Sample characteristics } & \multicolumn{4}{|c|}{ Perceived control over life (a) } \\
\hline & & & & \multicolumn{2}{|c|}{ In usual times } & \multicolumn{2}{|c|}{ During the pandemic } \\
\hline & & f & $\%$ & $\begin{array}{c}\text { \% High } \\
\text { level (4.5) }\end{array}$ & Mean & $\begin{array}{c}\text { \% High } \\
\text { level (4.5) }\end{array}$ & Mean \\
\hline \multirow[t]{3}{*}{ Gender } & Male & 63 & 20.7 & 68.3 & 3.94 & 38.1 & 3.21 \\
\hline & Female & 242 & 79.3 & 77.7 & 4.11 & 40.1 & 3.27 \\
\hline & Total & 305 & 100.0 & 75.7 & 4.08 & 39.7 & 3.26 \\
\hline \multirow[t]{4}{*}{ Age } & $<35$ & 94 & 31.0 & 67.0 & 3.95 & 31.9 & 3.11 \\
\hline & $35-50$ & 121 & 39.0 & 75.8 & 4.05 & 38.8 & 3.24 \\
\hline & $>50$ & 93 & 30.0 & 84.4 & 4.24 & 47.3 & 3.42 \\
\hline & Total & 308 & 100.0 & 75.7 & 4.08 & 39.3 & 3.25 \\
\hline \multirow[t]{3}{*}{ Education level } & Secondary or less & 64 & 21.1 & 73.0 & 4.11 & 50.0 & 3.53 \\
\hline & Higher & 239 & 78.9 & 76.3 & 4.07 & 36.8 & 3.18 \\
\hline & Total & 303 & 100.0 & 75.7 & 4.08 & 39.9 & 3.26 \\
\hline \multirow{3}{*}{$\begin{array}{l}\text { Employment } \\
\text { status }\end{array}$} & Employed, Self-employed & 213 & 70.1 & 76.8 & 4.09 & 39.0 & 3.25 \\
\hline & Other & 91 & 29.9 & 73.0 & 4.04 & 40.7 & 3.27 \\
\hline & Total & 304 & 100.0 & 75.7 & 4.07 & 39.5 & 3.26 \\
\hline \multirow{4}{*}{$\begin{array}{l}\text { Self-assessed } \\
\text { health (b) }\end{array}$} & Poor $(1,2)$ & 12 & 4.0 & 66.7 & 4.08 & 50.0 & 3.50 \\
\hline & Satisfactory (3) & 75 & 24.8 & 57.5 & 3.74 & 25.3 & 2.99 \\
\hline & $\operatorname{Good}(4,5)$ & 216 & 71.3 & 82.2 & 4.19 & 44.0 & 3.34 \\
\hline & Total & 303 & 100.0 & 75.6 & 4.07 & 39.6 & 3.26 \\
\hline \multirow{4}{*}{$\begin{array}{l}\text { Difficulties in } \\
\text { making ends } \\
\text { meet (c) }\end{array}$} & With no difficulty $(1,2)$ & 165 & 55.6 & 77.2 & 4.11 & 39.4 & 3.32 \\
\hline & Tightly managing (3) & 87 & 29.3 & 74.7 & 4.07 & 40.2 & 3.21 \\
\hline & With great difficulty $(4,5)$ & 45 & 15.2 & 70.5 & 3.95 & 37.8 & 3.13 \\
\hline & Total & 297 & 100.0 & 75.4 & 4.08 & 39.4 & 3.26 \\
\hline \multirow{6}{*}{$\begin{array}{l}\text { Type of } \\
\text { household } \\
\text { respondent is } \\
\text { living in }\end{array}$} & Living alone & 51 & 16.7 & 86.3 & 4.20 & 43.1 & 3.45 \\
\hline & With partner & 88 & 28.9 & 74.4 & 4.09 & 37.5 & 3.25 \\
\hline & With partner and child & 95 & 31.1 & 77.7 & 4.12 & 40.0 & 3.22 \\
\hline & With child & 32 & 10.5 & 80.6 & 4.16 & 53.1 & 3.53 \\
\hline & Else & 39 & 12.8 & 56.4 & 3.72 & 28.2 & 2.90 \\
\hline & Total & 305 & 100.0 & 75.7 & 4.08 & 39.7 & 3.26 \\
\hline
\end{tabular}

a. To what extent do you have control over your life, on a scale from 1 - "I have no control over my life" and 5 "I have control over my life", In usual times? During the pandemic?

b. How would you rate your health in general? (Answers were on the scale 1 - very bad, 2 bad, 3 - satisfactory, 4 - good, 5 - very good)

c. How would you describe the situation with income in your household? Which of the following descriptions is most appropriate? 1 - we can manage without any difficulty, 2 - we can just manage, 3 - we can manage with great difficulty, to 4 - we can manage with extreme difficulty.

Source: author's analysis based on original data. 
epidemic-driven occurrences, attitudes and actions of people in the specific setting of MABs in Ljubljana.

First, we describe how our sample is characterised: a high incidence of female, better educated, employed persons, mainly in good financial circumstances (55\% declaring no difficulty in making ends meet on their income) and in sound health (70\% rated it as good). In addition, younger and middle-age groups dominate and there is a high incidence (41\%) of children among household members.

The residents' response to the pandemic in terms of their perceived control over their life is measured by a question contained in the Slovenian public opinion poll (CJMMK, SJM 09/1; 11/1;13/1; Mandič, 2015). Respondents are asked to estimate the level of control over their life on a scale from 1 to 5, where 1 means "I have no control over my life" and 5 "I have control over my life". The question was adapted and posed first with the specification "in usual times" and then later with the specification "during the pandemic". The results show variation in perceived control across the sample and its subgroups and are given in Table 1.

A high level of control during the pandemic is declared by $40 \%$ of respondents, with the mean value of 3.26 being in the upper part of the scale. There is some variation across subgroups. Contrary to expectations, very little or almost no variation is found with regard to gender, employment status or financial situation. More variation is found across age groups (with control increasing with age) and regarding the education level (greater control among lower educated). There are differences with respect to health, but they are not simple linear. What stands out is the high level of control among single and single-parent households.

Still, when the level of control during the pandemic is compared to usual times, an alarming decrease is evident: the share of respondents with a high level of control (1,2) dropped from $75 \%$ to $35 \%$ during the pandemic. At the other extreme, the share of respondents with no or very little control rose

Table 2: ASSESSMENT OF RISKS

\begin{tabular}{|l|c|c|c|c|}
\hline $\begin{array}{l}\text { Item } \\
\text { Responses on a scale from } \\
\text { 1-not much to 5-very much }\end{array}$ & $\mathbf{1 , 2}$ & $\mathbf{3}$ & $\mathbf{4 , 5}$ & Mean \\
\hline How much have you felt at risk while meeting neighbours? & 230 & 37 & 37 & 1.88 \\
\hline How much have you felt at risk because of the Covid virus? & 144 & 97 & 67 & 2.65 \\
\hline How much have you felt at risk because of Covid's financial consequences for you? & 110 & 76 & 121 & 3.08 \\
\hline How much can you trust neighbours in usual times? & 75 & 104 & 123 & 3.24 \\
\hline How much have you been able to trust neighbours during the Covid pandemic? & 87 & 103 & 117 & 3.15 \\
\hline How safe have the common spaces in the building been regarding spread of the infection? & 62 & 72 & 149 & 3.44 \\
\hline
\end{tabular}

Source: author's analysis based on original data. 
from a marginal $4 \%$ to a substantial 28\%. The mean value dropped from 4.08 to 3.26, with an average drop of 0.82 . Groups indicating the biggest falls in control are those with the highest education levels (0.89 change), those who are only just managing with their current income (0.86) and those living with a partner and a child (0.85). On the other hand, groups seeing the smallest drops are those with a lower education (0.58), with poor health (0.58) and single parents (0.63).

Perceptions of risk with respect to various occurrences are described in Table 2. The biggest risk was seen as arising from possible personal financial consequences of the pandemic, exceeding the risks posed by the virus, while the smallest risk was seen as coming from meeting one's neighbours. The level of trust in one's neighbours has decreased during the pandemic, but remains positive, indicating the persistence of trust among neighbours. The common spaces were not perceived to be very risky.

Further, we examined various possible occurrences and activities that might have had happened in the MABs during the lockdown and were noticed by the respondents, as shown in Table 3.

Close to one-third of them reported the emergence of neighbourly support and help (a call to older residents to get help and the occurrence of 568 helpful neighbours bringing things). Somewhat less, but still reported by close to 20\%, were other forms of support among neighbours, as well as the common gatherings with music etc. by windows and on balconies. While a significant rise in tension and conflict was noticed within the household and reported by $26 \%$, a lower incidence (13\%) was perceived in contacts with neighbours, but still witnessing a noticeable change during the pandemic. However, the quite high number of incidents of disrespect of the anti-infection measures by residents in the building is noted.

Table 3: OCCURRENCES IN THE BUILDING DURING THE PANDEMIC AS

NOTICED BY THE RESPONDENTS

\begin{tabular}{|l|c|c|c|c|}
\hline \multicolumn{1}{|c|}{ Item } & No & Yes & \% Yes & Total \\
\hline $\begin{array}{l}\text { A notice in a visible place that invites older residents to contact specified people/ } \\
\text { institutions if needing assistance getting food, transport etc. }\end{array}$ & 221 & 89 & $28.7 \%$ & 310 \\
\hline Presence of humanitarian and voluntary organisations in the building or its surroundings & 281 & 29 & $9.4 \%$ & 310 \\
\hline Disrespect by residents of the measures against the spread of infection & 214 & 96 & $31.0 \%$ & 310 \\
\hline General increase in tension and conflicts in contacts between neighbours & 271 & 39 & $12.6 \%$ & 310 \\
\hline Increase in tension and conflicts within households & 228 & 82 & $26.5 \%$ & 310 \\
\hline Occurrence of neighbourly support/cooperation in getting things from shops, post etc. & 200 & 109 & $35.3 \%$ & 309 \\
\hline Occurrence of neighbourly support in care for vulnerable members (children, sick) & 245 & 63 & $20.5 \%$ & 308 \\
\hline Occurrence of psychological support among neighbours & 257 & 51 & $16.6 \%$ & 308 \\
\hline Jointly singing or playing music on windows or balconies at 6 p.m. & 256 & 52 & $16.9 \%$ & 308 \\
\hline
\end{tabular}

Source: author's analysis based on original data. 


\section{Impact of the occurrences in the building on perceived control over life - regression analysis}

We observe the individual's perception of being in control over their life during the Covid-19 pandemic and in the specific setting of an MAB. We seek to explain control over one's life and identify the factors responsible for

Table 4: VARIABLES IN THE REGRESSION ANALYSIS

\begin{tabular}{|c|c|c|}
\hline Construct & $\begin{array}{l}\text { Variable names } \\
\text { in the model }\end{array}$ & Variables and value labels \\
\hline Control & CONTROLLIFE & $\begin{array}{l}\text { At what level are you able to ascertain control over your life } \\
\text { during the pandemic lockdown? Answers were on a 5-point } \\
\text { Likert scale, with the following extreme values labelled ( } 1 \text { - } \\
\text { I do not control my life, ... } 5 \text { - I control my life) }\end{array}$ \\
\hline \multirow[t]{3}{*}{$\begin{array}{l}\text { Quality of } \\
\text { Life }\end{array}$} & HEALTH & $\begin{array}{l}\text { How would you rate your health in general? Answers were } \\
\text { on a 5-point Likert scale ranging from } 1 \text { - very bad to } 5 \text { - } \\
\text { very good, } 2 \text { - bad, } 3 \text { - satisfactory, } 4 \text { - good). }\end{array}$ \\
\hline & INCOME & $\begin{array}{l}\text { How would you describe the situation with income in your } \\
\text { household? Which of the following descriptions would be } \\
\text { most suitable? ( } 1 \text { - we can manage with the household s } \\
\text { income without problems, } 2 \text { - we can just manage with the } \\
\text { household s income, } 3 \text { - we can manage with difficulty, } \\
\text { to } 4 \text { - we can manage with the household s income with } \\
\text { extreme difficulty). }\end{array}$ \\
\hline & HOUSESPACE & $\begin{array}{l}\text { Was calculated by dividing the apartment's size in } \mathrm{m}^{2} \text { by } \\
\text { the number of residents. }\end{array}$ \\
\hline \multirow{5}{*}{$\begin{array}{l}\text { Control } \\
\text { variables }\end{array}$} & AGE & Age measured in years \\
\hline & EDUC & $\begin{array}{l}\text { Education. ( } 1 \text { - elementary school, } 2 \text { - high school, } 3 \text { - } \\
\text { higher education). For the purposes of modelling, the first } \\
\text { two categories were collapsed and labelled } 0 \text { (high school } \\
\text { or less), whereas the third category was labelled } 1 \text { (higher } \\
\text { education). }\end{array}$ \\
\hline & GENDER & Gender. Values: 0 - male and 1 - female \\
\hline & SIZE & $\begin{array}{l}\text { How many people are living in your household together } \\
\text { with you? }\end{array}$ \\
\hline & CHILD & $\begin{array}{l}\text { Type of household: Type of household (response } \\
\text { categories: Living alone, With partner, With partner } \\
\text { and child, With child) recoded 0: not having children in } \\
\text { household, } 1 \text { - having children in household }\end{array}$ \\
\hline \multirow[t]{3}{*}{$\begin{array}{l}\text { Quality } \\
\text { of the } \\
\text { neighbourly } \\
\text { response to } \\
\text { Covid }\end{array}$} & NEIGHSUP & $\begin{array}{l}\text { Count of types of support on three items on reported } \\
\text { occurrences of support in the building during the } \\
\text { pandemic (bringing things from grocery shops or the post } \\
\text { office, or the pharmacy, or maybe has started to receive } \\
\text { or give psychological support, assist in giving or receiving } \\
\text { help with care for a vulnerable person) }\end{array}$ \\
\hline & TRUSTNEIGH & $\begin{array}{l}\text { Perception of trust in one's neighbours during the } \\
\text { pandemic lockdown (Answers were on a 5-point Likert } \\
\text { scale, with the following extreme values labelled ( } 1 \text { - not at } \\
\text { all, } 5 \text {-can trust totally). }\end{array}$ \\
\hline & OLDSUPP & $\begin{array}{l}\text { Visible call by older residents about who to contact for help } \\
\text { to get food, transport etc. }(0-\text { no, } 1 \text { - yes })\end{array}$ \\
\hline
\end{tabular}

Source: author's analysis based on original data. 
its variability; in particular, the dependent variable is a resident's perceived control over their life during the pandemic lockdown (CONTROLLIFE), modelled by hierarchical linear regression analysis where variables are added to the model in separate steps called blocks. Apart from the QOL block and sociodemographic block, we focus on quality of the neighbourhood's response to Covid. Variables are presented in Table 4.

QOL variables are entered in the first block, followed by sociodemographic characteristics and quality of neighbourhood experience in the last block.

Table 5: REGRESSION ANALYSIS

\begin{tabular}{|c|c|c|c|c|c|c|c|c|c|c|c|c|}
\hline & \multicolumn{2}{|c|}{$\begin{array}{l}\text { Unstandardised } \\
\text { Coefficients }\end{array}$} & \multirow{2}{*}{ 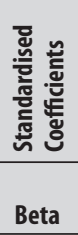 } & & \multicolumn{2}{|c|}{$\begin{array}{l}\text { Unstandardised } \\
\text { Coefficients }\end{array}$} & \multirow{2}{*}{ 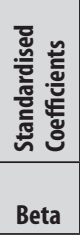 } & & \multicolumn{2}{|c|}{$\begin{array}{c}\text { Unstandardised } \\
\text { Coefficients }\end{array}$} & \multirow{2}{*}{ 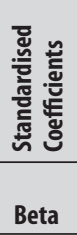 } & \multirow[b]{2}{*}{ Sig. } \\
\hline & b & $\begin{array}{l}\text { Std. } \\
\text { Error }\end{array}$ & & Sig. & b & $\begin{array}{l}\text { Std. } \\
\text { Error }\end{array}$ & & Sig. & b & $\begin{array}{l}\text { Std. } \\
\text { Error }\end{array}$ & & \\
\hline (Constant) & 3.260 & 0.382 & & 0.000 & 2.174 & 0.553 & & 0.000 & 2.038 & 0.540 & & 0.000 \\
\hline AGE & 0.013 & 0.005 & 0.150 & 0.012 & 0.012 & 0.005 & 0.141 & 0.021 & 0.009 & 0.005 & 0.102 & 0.088 \\
\hline EDUC & -0.374 & 0.172 & -0.129 & 0.031 & -0.482 & 0.177 & -0.166 & 0.007 & -0.487 & 0.169 & -0.168 & 0.004 \\
\hline GENDER & 0.017 & 0.167 & 0.006 & 0.920 & 0.020 & 0.165 & 0.007 & 0.905 & 0.021 & 0.157 & 0.007 & 0.893 \\
\hline SIZE & -0.144 & 0.079 & -0.147 & 0.068 & -0.085 & 0.083 & -0.086 & 0.310 & -0.100 & 0.079 & -0.102 & 0.207 \\
\hline CHILD & 0.222 & 0.189 & 0.093 & 0.240 & 0.226 & 0.187 & 0.095 & 0.227 & 0.198 & 0.178 & 0.083 & 0.268 \\
\hline HOUSPACE & & & & & 0.008 & 0.004 & 0.130 & 0.075 & 0.008 & 0.004 & 0.133 & 0.058 \\
\hline HEALTH & & & & & 0.242 & 0.081 & 0.171 & 0.003 & 0.159 & 0.079 & 0.112 & 0.045 \\
\hline INCOME & & & & & -0.081 & 0.073 & -0.067 & 0.267 & -0.081 & 0.069 & -0.067 & 0.243 \\
\hline NEIGHSUP & & & & & & & & & 0.159 & 0.077 & 0.130 & 0.039 \\
\hline TRUSTNEIGH & & & & & & & & & 0.133 & 0.057 & 0.137 & 0.021 \\
\hline OLDSUPP & & & & & & & & & 0.449 & 0.152 & 0.172 & 0.003 \\
\hline Sig.Fchange & 0.005 & & & & 0.002 & & & & 0.000 & & & \\
\hline R2 & 0.057 & & & & 0.104 & & & & 0.197 & & & \\
\hline Adjusted R2 & 0.040 & & & & 0.079 & & & & 0.166 & & & \\
\hline
\end{tabular}

a. Predictors: (Constant). CHILD. AGE. GENDER. EDUC. SIZE

b. Predictors: (Constant). CHILD. AGE. GENDER. EDUC. SIZE. HEALTH. INCOME. HOUSPACE

c. Predictors: (Constant). CHILD. AGE. GENDER. EDUC. SIZE. HEALTH. INCOME. HOUSPACE. OLDSUPP. TRUSTNEIGH. NEIGHSUP Source: author's analysis based on original data.

The demographic variables hold relatively weak explanatory power since by themselves they explain just $5.7 \%$ of the variance in CONTROLLIFE. The second model, when taking the QOL predictors into account, explains $10.4 \%$ of the variability in CONTROLLIFE. The final model, comprising all of the previous variables plus quality of the neighbourhood's response to Covid-19, explains $19.7 \%$ of the variability of CONTROL. The adjusted R2 is somewhat lower (16.6\%). 
In the final model, education $(b=-.487)$ has a significant effect on perception of control. The QOL block contributes a significant variable, i.e. the subjective perception of health $(b=.159)$ and HOUSEPACE (.008). The quality of the neighbourhood's response is contributed to by NEIGHSUP $(b=.159)$, TRUSTNEIGH $(b=.133)$ and OLDSUPP $(b=.449)$. The biggest change from the first to last model is seen for the variable AGE, that is initially significant (.0012) but, when controlled for neighbourhood, is no longer significant.

\section{Conclusion}

The pandemic has produced a host of new and unprecedented problems for countries, cities, organisations, social groups and individuals, which are responding to it in very different ways. As the pandemic continues, accounts are appearing about multiple adverse effects on people's lives and well-being. Numerous studies indicate the pandemic is associated with distress, anxiety, depression, uncertainty and economic difficulties, which may lead to psychiatric disorders (Sher, 2020). In Slovenia, a considerable rise in violent behaviour was reported in 2020 over 2019, namely a 9\% rise in domestic violence, $22 \%$ in rape and $59 \%$ in the number of minors taken into custody (Garbajs, 2021). People have clearly been deeply affected.

Our study aimed to provide insights into people's perceptions of having control in life during the pandemic while living in an MAB. This setting is special due to its particular sources of pandemic-associated hazards and the resources they have for coping with them. Our case study relies on data from Ljubljana and a survey of a purposive sample of $310 \mathrm{MAB}$ residents. The case study method was used due to its ability to offer a description and understanding of a phenomenon in its uniqueness/particularity, presenting a holistic perspective of real-life events in their complexity. The biggest challenge was to examine perceived control over life and its variation while accounting for diverse pandemic-driven occurrences in the building and among the residents during the lockdown in Ljubljana. It should be noted that the population under study is quite specific and represents a well-off part. The sample is characterised by the outstanding presence of female, younger, employed persons with a higher education and well off both economically and in terms of health.

Our results show a dramatic drop in perceived control over one's life, from $75 \%$ of respondents in usual times to $35 \%$ during the pandemic; at the opposite end, the very problematic state of the lowest level of control has skyrocketed from a marginal $4 \%$ to the alarming figure of $28 \%$. Some people have been seriously impacted, others much less so. Three groups with the highest levels of control (mean equal to or higher than 3.50) were those with the lowest education, in poor health, and single parents; groups 
with the lowest perceived control (mean below 3.12) were those under the age of 35 , those with satisfactory health, and those in atypical households. Among the sources of risks examined, the greatest perceived risk arose from possible personal financial consequences of the pandemic, somewhat less from the virus itself, and the least from meeting one's neighbours. Of the various occurrences and actions examined in the building during the lockdown, the most frequently reported (close to 30\%) were manifestations of neighbourly support in providing transport and the delivery of things, and also the considerable incidence of neighbours disrespecting the antiinfection measures.

Finally, in summarising the overall impact of the occurrences and the neighbourly action in the building, our regression analysis shows its significant effect on how residents have perceived their control over their life. The analysis also indicates a significant impact of various elements of quality of life and of basic socio-demographic characteristics, although the impact of the neighbourly occurrences is statistically twice as large. While quality of life and basic sociodemographic characteristics are already well recognised for their impact on perceived control over one's life, the neighbourly occurrences in an MAB have yet to be sufficiently examined. Since they stem from a case study, our results cannot be generalised but provide the grounds for further consideration of the housing setting and how it impacts quality of life and the sense of control over it. This means we may hypothesise that the type of setting, whether an MAB, a single-family house in a city residential area, or something else, may have a considerable impact on the individual's perception of having control over their life.

However, our case study also exposes some of the broader factors that influence individuals' control over life, with some clearly arising from the wider context. Namely, the significance of the neighbourly action and support might be a result of the reduced availability of other support network members due to mobility restrictions requiring one's own transport and within the borders of the municipality. As shown by Šadl and Hlebec (2018), family members play a key role in social support networks in Slovenia and might have been cut off by the restrictions. Moreover, in Slovenia the feeling of safety in one's neighbourhood is high compared to other European countries and social networks in the neighbourhood are strong (Filipovič Hrast, 2008).

Our results clearly confirm how important it is to holistically consider the context of perceived control over one's life. As a "differential spatiotemporal configuration of constraints and opportunities" (Moulaert et al., 2016), the setting of an MAB, as a space for residents to communicate and act together, has been shown to play a substantial role in our case. Although our study clearly shows that the setting of an MAB has provided a significant 
layer of human action in times of crisis, further research is called to permit generalisations.

\section{BIBLIOGRAPHY}

Bandura, Albert (1982): Self-efficacy Mechanism in Human Agency. American Psychologist 37 (2): 122-147.

Biron, Michal and Peter Bamberger (2010): The Impact of Structural Empowerment on Individual Well-being and Performance: Taking Agent Preferences, Selfefficacy and Operational Constraints into Account. Human Relations 63 (2): 163-191.

Bond, Michael J. and N. T. Feather (1988): Some Correlates of Structure and Purpose in the Use of Time. Journal of Personality and Social Psychology 55: 321.

Brown, Patric and Maria Grazia Galantino (2020): Understanding the Covid-19 Pandemic through the Sociology of Risk and Uncertainty (RN22). The European Sociologist 45 (1). Accessible at https://www.europeansociologist.org/, 10. 1. 2021.

Consolli, Teresa (2020): Sociological Experiencing and Reflecting - The Covid19 Emergency and the Sociological Memory. The European Sociologist 45 (1): Pandemic (Im)possibilities. Accessible at Sociological Experiencing and Reflecting - The Covid-19 Emergency and the Sociological Memory | European Sociologist, 10. 1. 2021.

Erikson, Robert (1993): Description of Inequality: The Swedish Approach to

Welfare Research. In Martha C. Nussbaum and Amartya Sen (eds.), The Quality of Life, 67-83. Oxford: Clarendon Press.

Etikan, Ilker, Sulaiman Abubakar Musa and Rukayya Sunusi Alkassim (2016): Comparison of Convenience Sampling and Purposive Sampling. American Journal of Theoretical and Applied Statistics 5 (1): 1-4.

Filipović, M. (2008): Influences on the Sense of Neighborhood: Case of Slovenia. Urban Affairs Review 43 (5): 718-732.

Giddens, Anthony (1981): A Contemporary Critique of Historical Materialism (1): Power, Property and the State. Berkeley, CA: University of California Press.

Gomm, R., M. Hammersley and P. Foster (eds.) (2000): Case Study Method: Key Issues, Key Texts. Sage.

Gutierrez, Lorraine M., Ruth J. Parsons and Enid Opal Cox (1998): Empowerment in Social Work Practice. CA: Brooks/Cole Publishing Co.

Koren, Paul, Neal DeChillo and Barbara Friesen (1992): Measuring Empowerment in Families: A Brief Questionnaire. Rehabilitation Psychology 37 (4): 305-321.

Kreisberg, Seth (1992): Transforming Power: Domination, Empowerment, and Education. SUNY Press.

Mandič, Srna and Maša Filipovič Hrast (2019): Homeownership in Multi-Apartment Buildings: Control beyond Property Rights. Housing, Theory and Society 36 (4): 401-425.

Mandič, Srna (2015): Opolnomočenje kot nova paradigma spreminjanja družbe in potencial v Sloveniji. Teorija in praksa 52 (5): 825-843.

Mirowsky, John and Catherine E. Ross (2007): Life Course Trajectories of Perceived 
Control and their Relationship to Education. American Journal of Sociology 112 (5): 1339-1382.

Moulaert, Frank, Bob Jessop and Abid Mehmood (2016): Agency, Structure, Institutions, Discourse (ASID) in Urban and Regional Development. International Journal of Urban Sciences 20 (2): 167-187.

Page, Nanette and Cheryl E. Czuba (1999): Empowerment: What Is It? Journal of Extension (online) 37 (5): 1-6.

Pfister, Sandra Maria (2020): The Social Definition of the Corona Pandemic. The European Sociologist 1 (45). Accessible at https://www.europeansociologist. org/, 10. 1. 2021.

Prenda, Kimberly M. and Margie E. Lachman (2001): Planning for the Future: A Life Management Strategy for Increasing Control and Life Satisfaction in Adulthood. Psychology and Aging 16 (2): 206.

Repohl, Martin (2020): Loss of World in Times of Corona. The European Sociologist $1(45)$.

Shulz, Amy, Barbara Israel, Mark Zimmerman and Barbara Checkoway (1993): Empowerment as a Multi-Level Construct. PCMA Working Paper \#40. Ann Arbor: The University of Michigan.

Serafini, Gianluca, Bianca Parmigiani, Andrea Amerio, Andrea Aguglia, Leo Sher and Mario Amore (2020): The Psychological Impact of Covid-19 on the Mental Health in the General Population. QJM: An International Journal of Medicine 113 (8): 531-537. Accessible at https://www.ncbi.nlm.nih.gov/pmc/articles/ PMC7337855/, 10. 1. 2021.

Seifert, Albert (2020): The Double Exclusion of Older Adults during the Covid-19 Pandemic. The European Sociologist 1 (45). Accessible at https://www.europeansociologist.org/, 30. 6. 2020.

Small, Mario L. (2009): 'How Many Cases Do I Need?'. On Science and the Logic of Case Selection in Field-based Research. Ethnography 10: 5-38.

Stake, R. E. (1995): The Art of Case Study Research: Perspective in Practice. London: Sage.

Staples, Lee H. (1990): Powerful Ideas about Empowerment. Administration in Social Work 14 (2): 29-42.

Šadl, Zdenka, Valentina Hlebec (2018): Družinska oskrba ostarelih staršev in spolne razlike v Sloveniji. Teorija in praksa 55 (4): 732-761, 957-958.

Sher, Leo (2020): The impact of the Covid-19 Pandemic on Suicide Rates. QJM: An International Journal of Medicine 113 (10): 707-712. Accessible at https://doi. org/10.1093/qjmed/hcaa202, 10. 1. 2021.

Stiglitz, Joseph, Amartya Sen and Jean-Paul Fitoussi (2009): The Measurement of Economic Performance and Social Progress Revisited. Reflections and Overview. Commission on the Measurement of Economic Performance and Social Progress, Paris.

Tamura, Kimiko, Winnie Hu, Lindsey Rogers Cook (2020): It s the Death Towers: How the Bronx Became New York s Virus Hot Spot. New York Times 26 May 2020. Accessible at https://www.nytimes.com/2020/05/26/nyregion/bronx-coronavirus-outbreak.html?searchResultPosition=1, 10. 1. 2021. 
Torales, Julio, Marcelo O'Higgins, João Mauricio Castaldelli-Maia and Antonio Ventriglio (2020): The Outbreak of Covid-19 Coronavirus and its Impact on Global Mental Health. International Journal of Social Psychiatry.

Thomas, Gary (2021): How to Do Your Case Study. Sage.

Vissak, T. (2010): Recommendations for Using the Case Study Method in International Business Research. Qualitative Report 15 (2): 370-388.

Zainal, Z. (2007): Case Study as a Research Method. Jurnal kemanusiaan 5 (1).

Yazan, B. (2015): Three Approaches to Case Study Methods in Education: Yin, Merriam, and Stake. The Qualitative Report 20 (2): 134-152. Accessible at http:// nsuworks.nova.edu/tqr/vol20/iss2/12, 10. 1. 2021.

Yin, R. K. (1984): Case Study Research: Design and Methods. Beverly Hills, Calif: Sage Publications.

Zimmerman, Marc (1990): Toward a Theory of Learned Hopefulness: A Structural Model Analysis of Participation and Empowerment. Journal of Research in Personality 24 (1): 71-86.

Žerdin, Ali (2021): MMXX: leto nevarne bližine; Ljubljana: UMco.

Xiong, J., O. Lipsitz, F. Nasri, L. Lui, H. Gill, L. Phan, D. Chen-Li, M. Iacobucci, R. Ho, A. Majeed and R. S. McIntyre (2020): Impact of Covid-19 Pandemic on Mental Health in the General Population: A Systematic Review. Journal of Affective Disorders 277: 55-64. Accessible at https://doi.org/10.1016/j.jad.2020.08.001, 10. 1. 2021.

\section{SOURCES}

Eurofound (2013): Third European Quality of Life Survey - Quality of life in Europe: Subjective Well-being. Publications Office of the European Union, Luxembourg.

Eurofound (2020): Living, Working and Covid-19, Covid-19 series. Publications Office of the European Union, Luxembourg.

Eurofound (2020): Living, Working and Covid-19 Dataset, Dublin. Accessible at http://eurofound.link/covid19data, 10.1.2021.

FDV CJMMK (2020) Slovensko javno mnenje 09/1; 11/1; 13/1.

Garbajs, Dejan (2021): Ali je v času koronavirusa več nasilja? Delo, 6. 1. 2021: 8. 